\title{
Babaring lelakon
}

\section{The use of -ing in Javanese genitive constructions}

\author{
DANIEL KRAUßE
}

\begin{abstract}
Two nominals in a genitive construction in Javanese are typically linked by the suffix -é in the low speech level and by -ipun in the high level, both of which are derived from the third person possessive suffix. There is a third suffix which links two nominals, namely -ing, which has so far received little attention in the literature. In this article, I present a syntactic and historical analysis of the suffix -ing. Of particular concern are four types of genitive constructions which permit the use of -ing, as opposed to two constructions where this suffix cannot be used.

KEYWORDS

Syntax; noun phrase; suffixation; Javanese.
\end{abstract}

\section{INTRODUCTION ${ }^{1}$}

Extensive studies have been carried out on the nominal phrase (NP) in Javanese (K. Baroroh and Mulyadi 2020; Gina et al. 1987; K. Hayward 1995; S. Nardiati et al. 1995; Nardiati 2007). However, the suffix -ing in genitive constructions has so far received little attention. Some authors analyse -ing as a (formal or

${ }^{1}$ I would like to thank the anonymous reviewers for their comments which have been very useful in improving the quality of this article. I also wish to express my gratitude to my main language consultants Anditya Rajasanagara and Neza Safitri for their help and grammaticality judgements of the Javanese expressions.

DANIEL KRAUßE is a PhD candidate in Linguistics at the University of Newcastle in Australia. In his doctorate program, he investigates the syntactic and semantic commonalities and differences between serial verb constructions in Oceanic languages and coverb constructions in Australian languages. He received his BA and MA degrees in Empirical Linguistics from the Goethe University of Frankfurt in Germany. In his master's thesis, he described the politeness system of the East Javanese variety spoken in Surabaya. His research interests include linguistic typology, historical linguistics, morphosyntax, and writing systems with a focus on the languages of Southeast Asia, in particular Thai, Indonesian, and Javanese. He has been awarded a number of linguistic scholarships and grants, including the ALS Research Grant 2019, the Indonesian language scholarship Darmasiswa from 2014 to 2015, and the Indonesian Arts and Cultural Scholarship BSBI in 2014. Daniel Krauße can be reached at: krausse.daniel@gmail.com. 
literary) substitute for the standard genitive suffix -é/-ipun with no difference in meaning or usage (L.P. Favre 1866: 84; J.J. Ras 1985: 20; S. Robson 1992: 34; Sukarno 2008: 194-195; D. van der Meij 2010: 353; Wedhawati et al. 2001: 220). ${ }^{2}$ Others attempt to draw a distinction between -ing and -é/-ipun (Gina et al. 1987: 113; H.N. Kiliaan 1919: 233; Nardiati 2016; T. Roorda 1855: 440-441). A detailed literature review follows in Section 3. The suffix -é/-ipun has the phonologically conditioned allomorphs -né/-nipun. The epenthetic / $\mathrm{n} /$ is used when the preceding root which it attaches to ends in a vowel. This is further explained in Section 4.

First, consider examples (1a) and (1b), in which the genitive suffix -é of the Ngoko speech level [NG] can be replaced by -ing with no change in meaning. The same is also true for -ipun of the Krama [KR] speech level in (2a) and (2b).

$$
\begin{aligned}
& \text { a. duwèk-é } \quad \text { wong } \\
& \text { possess-GEN person } \\
& \text { 'someone's possession' [NG] }
\end{aligned}
$$
b. duwèk-ing wong
possess-ING person
'someone's possession' [NG]
a. asma-nipun Gusti
name-GEN Lord
'name of the Lord' [KR]
b. asma-ning Gusti
name-ING Lord
'name of the Lord' [KR]

In contrast, the suffix -é/-ipun cannot be replaced by -ing in examples (3) and (4).

$$
\begin{array}{lll}
\text { anak-é }{ }^{*} \text {-ing } & \text { Mas } & \text { Budi } \\
\text { offspring-GEN/-ING older.brother } & \text { PN.M } \\
\text { 'a rich person's child' [NG] } &
\end{array}
$$

(4) asma-nipun/*-ning Bu Hartati

name-GEN/-ING Mrs PN.F

'Mrs Hartati's name' [KR]

In this article, I provide a detailed analysis of the suffix -ing and describe its functional range, constraints, and historical development. Except for a recent article by Nardiati (2016), no such study has been carried out to date.

Much of the data for this study comes from a searchable text corpus of written Javanese, which was generated by the website Sketch Engine prior to the research. The texts are drawn from the chronicle Babad Tanah Jawi (1939-

2 The suffix -é is used in the Ngoko speech level, whereas -ipun is the Krama equivalent. A feature of the Javanese language is an elaborate system of speech levels and honorifics, which need to be adhered to at all times in the spoken and written language. The three principal divisions are Ngoko (low level), Madya (mid-level), and Krama (high level). These speech levels mainly affect the lexicon, but to some extent also the morphology and syntax of the language. For a general overview of the Javanese speech levels, I refer the reader to S. Poedjosoedarmo $(1968,1969)$ and C. Geertz (1977). For a comparison between Central and East Javanese speech levels, see Kisyani-Laksono (2004) and Krauße (2018). Following Krauße (2018: 72), I treat the suffixes -é and -ipun as allolexes of a single 3sG.POss/GEN lexeme (see Section 2). 
1941), the oracle book Sêrat Jăngka Jayabaya (1938), the dictionary Baoesastra Djawa by W.J.S. Poerwadarminta (1939), the Javanese Bible Kitab Suci from Reksa Pustaka (1962), the online news magazine Pawarta Bahasa Jawa (2020), as well as five randomly selected Wikipedia pages in Javanese from 2020. The material mainly consists of formal texts because the suffix -ing is rarely used in the spoken language except in a few expressions and proverbs, which also form part of this study (see Section 5.6). Given that -ing is largely absent in East and West Javanese, this study concentrates on the Central Javanese variety. I am very grateful to the two native speakers of Javanese from Yogyakarta whom I have consulted for this study.

\section{SUFFIXES -é AND -ipun}

To follow the ensuing discussion on the suffix -ing, some background information on the genitive construction in Javanese is necessary. The suffixes which I term "genitive" here are derived from and identical to the possessive suffixes for the third person. The expression of possession in Standard Javanese is introduced first.

Singular pronominal possession on the Ngoko level (examples a) is conveyed by the suffix $-k u$ for the first person (5), by $-m u$ for the second person (6), and by -éfor the third person (7). On the Krama level (examples b), independent pronominal forms are employed for the first and second person singular, whereas the third person takes the suffix -ipun.

a. bapak-ku

father-1sG.POss

'my father' [NG]

(6)

(7) a. bapak-mu

father-2sG.POSS

'your father' [NG]

a. bapak-é

father-3sG.POss

'his/her father' [NG] b. rama kula

father 1sG

'my father' [KR]

b. rama panjenengan

father 2SG

'your father' [KR]

b. rama-nipun

father-3sG.POss

'his/her father' [KR]

The plural forms are not relevant to this study and they vary by region. I refer the reader to M.C. Ewing (2010: 29-31) for the set of pronouns in West Javanese, to E.M. Uhlenbeck (1960: 3-14) and B. Arps et al. (2000: 96-100) for the pronominal forms in Central Javanese, and to Krauße (2017: 32-36) for those used in East Javanese. The focus of this article is the suffix -é/-ipun.

Apart from possession, -é/-ipun can mark definiteness and function like the definite article in other languages (see C. Lyons 1999: 47 and further). R. Wessing (2015: 433) terms it an "associative suffix". S. Villerius (2018: 70) refers to -é as a "determiner/possessive suffix" and glosses it as a marker of definiteness throughout her thesis. According to Krauße (2017: 
37), nominalization and genitive are two other functions of -(n)é in East Javanese. Arps et al. (2000: 43) distinguish three functions of -é/-ipun, namely definiteness, third person possession, and linker of two independent nouns.

Consider example (8) for the Ngoko level and (9) for the Krama level. Here, the suffix -él-ipun does not denote that the sun or the city are possessed, but that they are unique objects and that no other such entity exists. There is only one sun in the universe, and there is only one city called Manila, hence they are definite.

(8) Ésuk-ésuk srengenge-né lagi m-etu, sibu. morning RED sun-DEF PROG AV-emerge mother 'In the early morning, the sun comes out, Mother.' [NG]

(9) Artikel punika namung m-bahas kitha-nipun; Ø-pirsa-ni article DEM only AV-discuss city-DEF IMP-see-APPL "Metro Manila" kanggé artikel bab laladan metropolis-ipun. PN.GEO for article about territory metropolis-DEF 'This article only discusses the city; see Metro Manila for the article about the metropolitan area.' [NG]

In cases in which the status or honorific of the addressee is not known, the suffix -é/-ipun is used as a form of avoidance. In example (10), the referentiality of $-e ́$-ipun is ambiguous, as indicated in the translation.

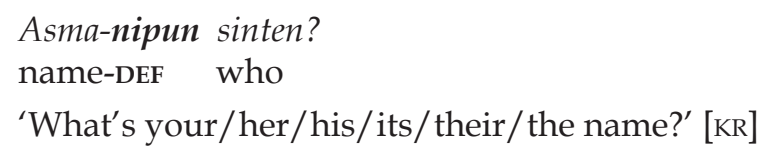

The correlation between the third person possessive and definiteness has also been observed in other languages of the region, such as Indonesian -nya (P. Grangé 2015; J.N. Sneddon 2010: 155-156) and Balinese-(n)é (A. Shiohara and K. Artawa 2015). When the suffix -éf-ipun denotes definiteness or possession of the third person, it cannot be replaced by -ing, exemplified by the ungrammatical phrases in (11), (12), and (13).
a. *bapak-ing father-ING
(intended: 'his/the father') [NG]
b. *rama-ning father-ING (intended: 'his/the father') [KR] 
(18)

$$
\begin{array}{lll}
\text { pucuk-él-ing } & \text { Gunung } & \text { Merapi } \\
\text { summit-GEN/-ING } & \text { mountain } & \text { PN.GEO } \\
\text { 'the top of Mt Merapi' [NG] } &
\end{array}
$$

The aim of this article is to investigate the use and function of the suffix -ing. In Section 5, I show why the constructions in (14) and (15) do not permit the suffix -ing, whereas the constructions in (16) to (18) do.

\section{Previous Research}

Favre (1866: 84), Robson (1992: 34), Sukarno (2008: 194-195), and Wedhawati et al. (2001: 220) state that the suffixes -é/-ipun and -ing in a genitive construction in Javanese have no difference in meaning and function. Ras (1985: 20) and Van der Meij (2010: 353) claim that -ing is a formal substitute of -é/-ipun. Native speakers of Javanese also typically regard -ing as a formal and literary suffix. In this section, I only discuss the literature in which a clear difference between -é/-ipun and -ing is drawn.

Roorda (1855: 440-441) argues that -ing cannot be used when two definite objects are conceived as real objects and are in some relation to each other. He states that in such cases, -é/-ipun must be used.

This suffix -ing [...] is mainly used: firstly, when the genitive attribute refers to just the nature or quality of the first mentioned object [...]; and secondly, when the first object is imagined as an adjunct or event onto the second; for example, in rasaning atiku 'the feeling of my heart'. But when two definite and special objects are conceived as real objects and in real relation to each other, this relation is expressed only by the possessive pronoun, and not figuratively by the preposition or suffix -ing as a mere logical one. Therefore, they say for example, anaké tanggaku 'the child of my neighbour', and not anaking tanggaku, as they say anaking tangga for 'the neighbour's child' or 'a neighbour's child', and pangrasaning tanggaku 'feelings of my neighbour'. ${ }^{4}$

It seems that Roorda's consultants accepted anaking tangga 'the neighbour's child' but not anaking tanggaku 'my neighbour's child'. This observation is not confirmed by my language consultants, nor do the corpus data reveal such a difference.

Kiliaan (1919: 233) observes three uses of -ing which distinguish it from -é/-ipun. These concern the lexical meaning, the style, and the phonology of

${ }^{4}$ Dutch original: “Dit aanhechtsel å nu [...] is voornamelijk in gebruik: $1^{\circ}$. wanneer men met het Genitief attribuut alleen een aard of hoedanigheid van het eerstgenoemde voorwerp beteekenen wil [...]; en $2^{\circ}$. wanneer men het eerste voorwerp zich voorstelt als adjunct of accident aan

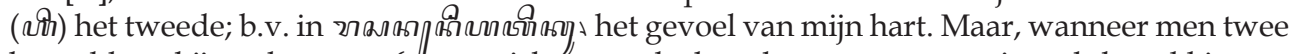
bepaalde en bijzondere voorwerpen zich voorstelt als reële voorwerpen en in reële betrekking tot elkander; dan wordt deze betrekking alleen door het bezittelijk voornaamwoord uitgedrukt, en niet figuurlijk door het voorzetsel of aanhechtsel an als een louter logische aangeduid. Zoo zegt

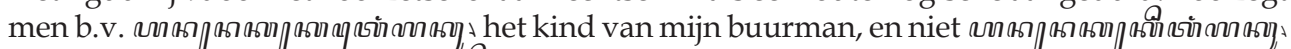

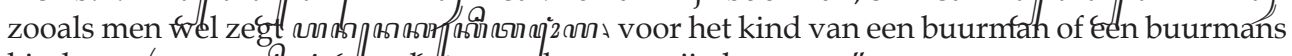

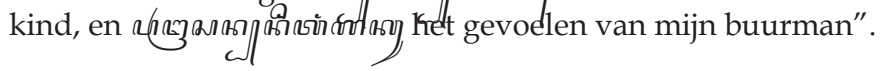


the constituents in the genitive NP. He argues that -ing is preferred to -é/ipun when (i) the second constituent of the NP has an abstract meaning, (ii) the genitive or possessive NP consists of more than two elements, so that a sequence of same suffix is avoided, or (iii) the second NP constituent begins with a vowel.

Instead of $e$ (ne), ing (ning) can occur as a suffix when the determining word immediately follows it and has an abstract and general meaning, for example lunjuning (or lunjune) wĕlut 'the slipperiness of an eel', djogeding (or djogede) badaja 'the dance of a court dancer'. - If the particular word is a concrete noun, nothing but ing (ning) can be used as a suffix, for example, anaqing sapi iku aran pĕdet, 'the young of a cow is called calf'. In this case, however, the suffix can be omitted: anaq sapi. - Furthermore, it is common to say ing (ning) after the determining word 1) when it is followed by an adjunct with $e$ (ipun K.) to avoid two e $e^{\prime}$ s or ipun's, for example, undaqing rĕgane $\mathrm{N}$., indaqing (or indaqe) rĕginipun $\mathrm{K}$. 'the raising of the price'; - 2) when the first word is determined by a vowel-initial word, for example, karsaning Allah 'God's pleasure', rasaning atiku N., and accordingly: raosing manah kula K. ' (according to) the feelings of my heart'. ${ }^{5}$

While my consultants confirm that anak sapi 'the young of a cow' is the most common expression, they do not accept anaking sapi. This use of -ing also does not occur in my corpus. It is very likely that anak sapi is understood as a nominal compound (see Section 5.5.2), therefore disallowing the occurrence of the suffix -ing and not as a possessive construction, which would permit the use of -ing (see Section 5.1). Kiliaan argues that anaké sapi is ungrammatical, but this is accepted by my consultants, although it is rarely used. Kiliaan's example sentence would be anak sapi iku aranéfjenengé pedhet 'the young of a cow is called calf' in contemporary Javanese. His example djogeding/djogede badaja, now spelled jogèding bedhaya, is not a meaningful expression in Javanese because bedhaya does not mean 'court dancer' but 'court dance'. Therefore, jogèding bedhaya would mean 'dance of the court dance', which is not accepted by my consultants. Instead, the correct expression is jogèd bedhaya 'court dance' as a nominal compound, described in more depth in Section 5.5.2.

Roorda's explanation is reminiscent of Kiliaan's hypothesis that -ing is used when the second constituent of the genitive construction has an abstract meaning. From the following examples, it seems that -ing cannot be used when the two constituents in the NP refer to real persons. Compare example (19),

\footnotetext{
${ }^{5}$ Dutch original: "In plaats van $e$ (ne) kan ing (ning) als suffix voorkomen wanneer het bepalende woord er onmiddellijk op volgt en abstracte, algemeene beteekenis heeft; b.v. lunjuning (of lunjune) wělut, de gladheid van een aal, djogeding (of djogede) badaja, de dans van een hofdanseres. - Is het bepaalde woord een concreet substantief, dan kan zelfs niets anders dan ing (ning) als suffix gebezigd worden; b.v. anaqing sapi iku aran pẹdet, het jong van een koe heet kalf. In dit geval kan het suffix echter weggelaten worden: anaq sapi. - Wijders zegt men 't liefst ing (ning) achter het bepaalde woord 1) wanneer dit door een bepaling met $e$ (ipun K.) gevolgd wordt om twee $e^{\prime}$ s of ipun's te vermijden; bv. undaqing rĕgane N., indaqing (of indaqe) rĕginipun $\mathrm{K}$., de verhooging van den prijs; - 2) wanneer het eerste woord door een met een klinker beginnend woord bepaald wordt; b.v. karsaning Allah, Gods welbehagen, rasaning atiku N., en dienovereenkomstig: raosing manah kula K., (naar) het gevoelen van mijn hart".
} 
which is an excerpt of a classical version of the Javanese Bible, with example (20), which is from the contemporary version of the same verse, in which the suffix -ing has been replaced by -é. Because Zebedeus is neither a real nor a living person and instead perceived as a figure from the past, either -ing or -é can be attached to anak 'offspring'. However, in a context in which a person named Yakub is described as the son of a woman named Bu Dewi, who is a real person and still alive, the suffix -ing is not permitted (21). In such cases, only-é/-ipun is possible (22). The use of -ing is blocked before proper names which refer to humans of the present and of the mortal world (see Section 5.5.1 for more examples).

$\begin{array}{lll}\text { Yakobus anak-ing } & \text { Sebédayu. } \\ \text { PN.M } & \text { offspring-ING } & \text { PN.M }\end{array}$

'Jacob was the son of Zebedee.' [NG] (Kitab Suci Jawa 1962, Matius 10:2)

(20) Yakobus anak-é Zébédéus.

PN.M offspring-3sG.POss PN.M

'Jacob was the son of Zebedee.' [NG] (Alkitab Mobile 2006, Matius 10:2)

(21) *Yakub anak-ing Bu Déwi.

PN.M offspring-ING Mrs PN.F

(intended: 'Jacob is the son of Mrs Dewi.') [NG]

(22) Yakub anak-é/-ipun Bu Déwi.

PN.M offspring-3sG.POss Mrs PN.F

'Jacob is the son of Mrs Dewi.' [NG]

Both Kilian and Roorda use the example rasaning atiku 'the feeling of my heart', which is indeed a very common genitive construction in Javanese. Roorda states that anaké tanggaku is the standard way to express 'the child of my neighbour', whereas anaking tanggaku is ungrammatical. This is confirmed by my consultants. On the other hand, Roorda argues that anaking tangga 'the neighbour's child' is possible, which is deemed ungrammatical by both of my consultants.

Kiliaan (1919: 233) also states that the suffix -é/-ipun in a longer NP is replaced by -ing to avoid a repetition of the same suffix. C. Poensen (1897: 235) also explains that "-ing as a preposition" can be used in lieu of -é/-ipun for euphonious reasons. For example, both (23) and (24) are well-formed NPs, but (23) is more euphonious than (24) and is therefore preferred in the literary language and in set phrases. The construction in (24) is more commonly used in the spoken language.

(23) indhak-ing regi-nipun

rise-GEN price-DEF

'increase in the price' [KR] (Kiliaan 1919: 233) 
(24) indhak-ipun regi-nipun

rise-GEN price-DEF

'increase in the price' [KR] (Kiliaan 1919: 233)

Gina et al. (1987: 113) attempt to draw a difference between -é/-ipun and -ing by stating that there needs to be some physical contact between the head of the NP and its modifier, insofar as the NP head can be "worn by or placed on its modifier". ${ }^{6}$ They cite the example jenenging negara 'name of the state' because the name is "worn by" or is part of the state.

Nardiati (2016: 94-95) describes four nominal relations which are conveyed by the suffix -ing, namely possession, part-whole, agentive, and goal. She also discusses a rare type of genitive expression involving the repetition of the same nominal (Nardiati 2016: 93). In Section 5, I discuss three of Nardiati's types, which I term possessive relation, meronymic relation, and subject relation. She has no examples of the fourth type which I have identified, namely object relation.

\section{ETYMOLOGY OF -ing}

Javanese has the genitive suffix -ing and also the phonologically identical preposition ing, which exists in dialectal variation with ning. It is worth noting that the genitive suffix and the preposition are written differently in Hanacaraka, the traditional Javanese writing system. Hanacaraka is an abugida, the basic elements of which are consonant letters and vowel diacritics. Consonant clusters are written as stacked consonants. Vowel diacritics, except for the inherent vowel /a/ (realized as [0] in open syllables), are placed around the preceding consonant or consonant cluster. For an overview of the writing system and its rules, see Darusuprapta (2002). The crucial point for this article is that vowel-initial suffixes such as -ing, $-e$, and -ipun receive an epenthetic $/ \mathrm{n} /$ which is written twice when they attach to a final vowel of the base word, for example, rasaning 'feeling of' is written as

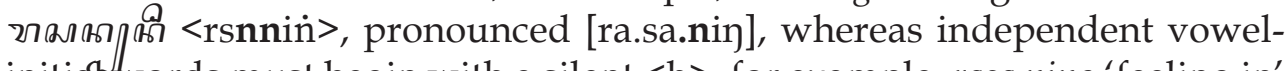
initiat words must begin with a silent $<\mathrm{h}>$, for example, rasa ning 'feeling in' is written as длалаด <rshini $>$, pronounced [ro.so in]. With this in mind, we can easily identify in Hanacaraka whether /in/ is the genitive suffix -ing or the preposition ing.

Various hypotheses concerning the history and development of the suffix -ing have been put forward. Hypothesis 1 is normally offered by native speakers of Javanese, stating that -ing has simply grammaticalized from the preposition $(n) i n g$ ' in'. This hypothesis proposes that an expression like rasaning atiku 'the feeling of my heart' is derived from rasa (n)ing atiku 'the feeling in my heart'. Hypothesis 2 is similar but adds that the suffix has developed from -é+ing (Roorda 1855: 441, 1874: 167), that is, the possessive

\footnotetext{
${ }^{6}$ Indonesian original: “[...] kalau intinya berupa nomina yang dapat dikenakan atau ditempatkan pada modifikatornya, hubungan antara inti dan modifikatornya dapat dinyatakan dengan -ing."
} 
suffix (see Section 2) and the preposition ing. This hypothesis proposes that rasaning atiku is derived from rasané ing atiku 'the/his/its feeling in my heart'. According to Hypothesis 3 , the suffix -ing is a contraction of the Old Javanese linking element $n i$ and the article $\dot{n}$, resulting in the 'particle nin' (Nardiati 2016: 87). This hypothesis is backed by the fact that genitive constructions like warna nin kuda 'colour of the horse' are attested in Old Javanese (A.S. Teselkin 1972: 50).

Each of the three hypotheses is explored below. Of these, I show that Hypothesis 3 is best supported, whereas the other two appear to be folk etymology. The following grammaticalization paths are imaginable $(\mathrm{MJ}=$ Modern Javanese, $\mathrm{OJ}=$ Old Javanese, $\mathrm{H}=$ head, $\mathrm{M}=$ modifier).

$$
\begin{array}{ll}
\text { Hyp1 } & \text { MJ: } \mathrm{H}+i n g+\mathrm{M} \rightarrow \mathrm{MJ}: \mathrm{H}-i n g+\mathrm{M} \\
\text { Hyp2 } & \text { MJ: } \mathrm{H}+-(n) e ́+i n g+\mathrm{M} \rightarrow \mathrm{MJ}: \mathrm{H}-(n) e ́ \text { ing }+\mathrm{M}>\mathrm{H}-(n) i n g \mathrm{M} \\
\text { Hyp3 } & \text { OJ: } \mathrm{H}+n i+\dot{n}+\mathrm{M} \rightarrow \mathrm{MJ}: \mathrm{H}-n i n g+\mathrm{M}
\end{array}
$$

In order to investigate these hypotheses, a short introduction to the genitive construction in Old Javanese is necessary. There are three ways to relate two nominals in Old Javanese, two of which include the particles $(n) i n$ and $(n) i k a \dot{n}$ after the head nominal. Dwi Puspitorini (2015: 61) analyses (n)in as a definite and $(n) i k a \dot{n}$ as an indefinite-specific oblique particle. The variation between the forms with and without the epenthetic / $\mathrm{n} /$ is phonologically conditioned (explained below). The particle (n)in consists of $(n) i$ (also explained further below) and the definite article (a) $\dot{n}$. The particle $(n) i k a \dot{n}$ consists of $(n) i$, the demonstrative ika 'that', and the definite article $(a) \dot{n}(\mathrm{~W}$. van der Molen 2015: 20-21). While Van der Molen (2015) writes (n)in and (n)ikan as suffixes on the head noun, they are treated as separate words by Teselkin (1972: 50) and by M.S. Zurbuchen (1976). I follow the traditional spelling as separate words for Old Javanese in this article. H. Kern (1871: 34) says that nin is an "amplified form" of $n i$ and that $n i$ is an alternative form of the locative preposition $i$ 'in, at'.

The Modern Javanese preposition ing is also a contraction of the Old Javanese locative preposition $i$ and the definite article (a) $\dot{n}$ (P.J. Zoetmulder and S.O. Robson 1982: 664). Therefore, all three hypotheses above have in common that they involve the Old Javanese article $(a) \dot{n}$ of some sort.

The Old Javanese genitive particle is nin for consonant-final and vowelfinal nominals ( $25 \mathrm{a}$ and $25 \mathrm{~b}$ ) but in when it attaches to nominals whose final sound is $/ \mathrm{n} /(25 \mathrm{c})$. Old Javanese also allows verb roots like $t i b \bar{a}$ ' fall' to occur as the head of a genitive NP (25d). The examples below are all taken from Van der Molen (2015: 20-21). For more examples of Old Javanese genitive constructions, see Dwi Puspitorini (2015: 105-106).

$$
\begin{aligned}
& \mathrm{N}+-n i+\dot{\mathrm{n}}+\mathrm{N} \rightarrow \mathrm{N}-(n) i n \mathrm{~N} \\
& \text { a. } \quad \text { lin } n i-\dot{n} \quad \text { guru } \\
& \text { word GEN-DEF.ART teacher } \\
& \text { 'the word of the teacher' }
\end{aligned}
$$



b. krama ni-ñ śişya
behaviour GEN-DEF.ART pupil
'the behaviour of the pupil'
c. ṅaran $i-\dot{n}$ dewatā
name GEN-DEF.ART god
'the name of the god'
fall GEN-DEF.ART rain
'the falling of the rain'7
d. tibā ni-n hudan

The second possibility to express a relationship between two nominals in Old Javanese involves the particle (n)ikan. Its form is nikain when it follows consonant-final and vowel-final nominals (26a), but it is spelled as ikan when it is preceded by a nominal whose final sound is /n/ (26b).

$$
\begin{aligned}
& \mathrm{N}+(n) i+i k a+\dot{n}+\mathrm{N} \rightarrow \mathrm{N}-(n) i k a \dot{n} \mathrm{~N} \\
& \text { a. lin } \dot{n} i-k a-\dot{n} \text { rākșasa } \\
& \text { word GEN-DEM.DIST-DEF.ART demon } \\
& \text { 'the word of the demon' } \\
& \text { b. naran } i-k a-\dot{n} \text { rare } \\
& \text { name GEN-DEM.DIST-DEF.ART child } \\
& \text { 'the name of the child' }
\end{aligned}
$$

When the modifying nominal in the genitive construction is already definite because of a possessive suffix, the definite article is not used (27a), whereas ni remains obligatory (Van der Molen 2015: 21). In a genitive construction with three nominals, the presence of nikan on the second member demands that the first member do not take the definite article (27b), although this rule is not consistently applied, as shown in example (27c).

$$
\begin{aligned}
& \mathrm{H}+-n i+\mathrm{M}-\mathrm{POSS}>\mathrm{H}-n i \mathrm{M}-\tilde{n} a \\
& \text { a. lawas ni hurip-ña } \\
& \text { long.time GEN life-3sG.POSs } \\
& \text { 'the length of his life' }
\end{aligned}
$$

\footnotetext{
7 When the locative preposition $i$ and the definite article $\dot{n}$ follow tib ' 'fall', it attaches to the verb and undergoes sandhi: tibĕng $(<t i b \bar{a}+i+\dot{n})$ lemah 'fall on the ground' (Teselkin 1972: 55).
} 

b. kweh ni wulu ni-ka-n kuda number GEN body.hair GEN-DEM.DIST-DEF.ART horse 'the number of the hairs of the horse'
c. kweh $n \dot{n}-\dot{n} \quad$ wadya $n i-k a-\dot{n} \quad$ Dhrștadyumna number GEN-DEF.ART troops GEN-DEM.DIST-DEF.ART PN.M 'the number of the troops of Dhrishtadyumna'

The genitive particle $n i$ is not used when the person article si (28a) or the honorific article san $(28 \mathrm{~b})$ precedes the modifying nominal.

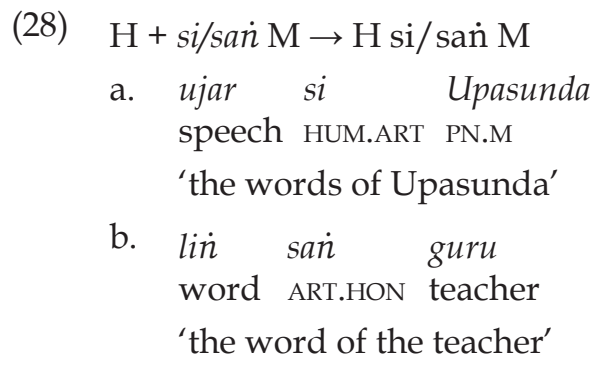

Considering the various types of genitive NPs in Old Javanese, it is very likely that the Modern Javanese genitive suffix -ing and its allomorph -ning are a direct continuation of Old Javanese nin and not an ad hoc formation out of the Modern Javanese preposition ing. At first sight, Hypothesis 1 seems to be the most plausible because it directly yields the desired form $\mathrm{N}-(n)$ ing. However, this would require a semantic extension of the locative meaning 'in, at' to a general genitive suffix, which ignores the Old Javanese genitive particle ni. Hypothesis 2 does not take Old Javanese into consideration because the suffix -(n)é did not exist back then. Its equivalents were -ña and -nira (Uhlenbeck 1968: 467; Van der Molen 2015: 25). I argue that Hypothesis 3 is best supported and that the genitive particle $n i$ in Old Javanese in combination with the definite article, yielding $(n) i n$, has developed into the genitive suffix -ning in pre-Modern Javanese. This form was later re-analysed as a suffix with an epenthetic $/ n /$, just like -(n)é and -(n)ipun. The alternation between vowel-initial and nasal-initial suffixes did not exist in Old Javanese and is only attested from a later stage of the language. This has led to doublets in the literature, for example, sa $(k)$ rèhning vs. sa(k) rèhing 'in view of the fact that' and sakwèh-ning vs. sakwèh-ing 'all', as well as to free variation across the different varieties of Javanese, for example, bapak-né vs. bapak-é 'his/her/the father'. See Uhlenbeck (1968: 474) for a similar observation.

The epenthetic / $\mathrm{n} /$ is only used for the three suffixes -é,-ipun, and -ing in the nominal domain and the locative applicative suffix $-(n) i$ in the verbal domain. ${ }^{8}$ In contrast, the verbal applicative suffix -aké (NG)/-aken (KR) does not require an

\footnotetext{
${ }^{8}$ The opposition between the vowel-initial and the /n/-initial forms of these suffixes is attested
} from all varieties of Modern Javanese. 
epenthetic /n/ but an epenthetic glottal stop instead, for example, waca / wo.tjo/ 'read' > macak-aké / ma.tja?.a.ke/ 'read for someone', priksa / prik.so/ 'know, see' > mriksak-aken /mrik.sa?.a.kən/ 'show, inform'. The irrealis/imperative suffix $a$ /o/ has no glottalizing effect, for example, teka / to.ko/ 'come' > teka-a /tə.ko.o/ 'come here!'

The fact that the epenthetic / $\mathrm{n} /$ is consistently employed on the three suffixes $-e$, -ipun, and -ing suggests that they have undergone a similar development. The suffix -(n)é is most likely from Old Javanese - $\tilde{n}$ (discussed above), which has an alternative form - $y a$ when it attaches to a root which ends in /n/ (Uhlenbeck 1968: 468). The Krama equivalent ipun has no known etymology, but the demonstrative-possessive pronoun nipun 'his, her, their' with the alternative ipun after /n/ is attested in Old Javanese (Zoetmulder and Robson 1982: 1438). Considering these observations, it is very likely that the suffix -ing has similarly developed from Old Javanese ( $n) i+i n$, confirming Hypothesis 3.

\section{UsE OF -ing}

In this section, I explore the use of the genitive suffix -ing. As foreshadowed in Section 3, and as other researchers have found out, the suffix -ing cannot be used in all cases in which a genitive construction is possible in other languages. Consider sentence (29), in which the suffix is used between the numeral sadasa 'ten' and the nominalized adverb waunipun 'before' to indicate a relationship between the current number and the (implied) number from before, somewhat like 'the tenth time of the previous'. In the second case, -ing links the nominalized adverb pindha 'like, as' to the nominal kajeng agaran 'firewood' to create the genitive NP 'the resemblance of firewood'.

Wondéné Sang Parta anggè-nipun m-esu sarira saya
as.for ART.HON PN.M use-GEN AV-make.effort body more.and.more
banter tikel kaping sa-dasa-ning waunipun. kados pe-pindha-ning fast great.than times one-ten-GEN before-DEF like RED $\sim$ resemble $\sim_{\text {GEN }}$ kajeng agaran vsampun bêntèr mèh ng-ukus. wood rubbing already hot almost AV-steam

'As for Sang Parta he's using his body's utmost effort to be more than ten times as fast as before, resembling firewood which has become hot and almost steams.' [KR] (Pusaka Jawi 1935: 94)

In the ensuing discussion, I present four construction types in which the suffix -ing can be used, along with two types in which it cannot be used. The final part of this section is an overview of fixed expressions which contain -ing.

\footnotetext{
${ }^{9}$ While there is great variation of the suffix -aké across the dialects of Javanese, -aken and -en are more stable. The suffix $-i$ is stable across all varieties of Javanese. For an overview of their distribution and etymology, see A. Adelaar (2011).
} 


\subsection{POSSESSIVE RELATIONS}

One of the major functions of the genitive suffix -ing is to serve as a linker between the possessor and the possessum. This construction is known as genitious possessious in Latin grammars. It is typical of the languages of western and central Indonesia that the possessum precedes the possessor. Possessive relations in Javanese with -ing are formed according to the formula in (30), which can be tested by paraphrasing it as in (31).

(30) N2 possesses N1 $\rightarrow$ N1-ing N2

(31) N1 duwèké N2

The formula in (30) states that it is always the possessum which receives the suffix -ing. The examples in (32) to (40) exemplify this possessive relationship between two nominals. A number of these NPs are taken from various sources, for example, Gina et al. (1987: 38-39), Poerwadarminta (1939: iii, 28), and common proverbs (see Section 5.6), while others are from the source texts which formed my corpus for this study (see Section 1). My consultants have confirmed that the NPs in (32) to (40) are grammatical and also commonly used in contemporary Standard Javanese.

(32) jiwaning manungsa

(33) asmaning Gusti

(34) putraning Déwa

(35) pangajabing rakyat

(36) pusakaning Déwa

(37) duwèking wong

(38) kakuwataning wong akèh

(39) kridhaning manungsa

(40) para empuning basa Jawi

(41) dhemenan karo bojoning liyan ${ }^{10}$ 'human soul' (lit. 'soul of the human being')

'name of God'

'son of the deity'

'hope of the people'

'heirloom of the deity'

'someone's possession' (lit. 'having of a person')

'strength of many people'

'pleasure of man'

'masters of the Javanese language'

'pleasure with the partner of someone else'

\subsection{MERONYMIC RELATIONS}

A meronym is a lexeme which constitutes a part of something else. This partwhole relationship is often expressed by the genitive suffix -ing in Javanese. In all cases discussed below, this suffix can be replaced by -é/-ipun. The formula for meronymic relations is set out in (42) and it can be tested with the Javanese paraphrase in (43).

\footnotetext{
${ }^{10}$ An anonymous reviewer remarks that we would expect liya-né 'other-NMLz' in this example. The phrase in (41) is taken from Poerwadarminta (1939: 28). The form liyan, perhaps originating from liya-an, is also listed in S. Robson and S. Wibisono (2002: 449) with the translation 'another, others'. The difference between liya and liyan in Standard Javanese is that liya is an attribute which modifies a nominal, for example, wong liya-né 'the other person' whereas liyan is used in predicative position and as a nominal, for example, rasané liyan 'the feelings of the others'.
} 
(42) N1 is part of N2 $\rightarrow$ N1-ing N2

(43) N1 ya iku bagéan saka N2

The formula states that, if the first nominal is part of the second nominal, the suffix -ing attaches to the first nominal. Some selected examples are provided in (44) to (53).

(44) pucuking gunung

(45) lacining méja

(46) cendhelaning bis

(47) rambuting pari

(48) soroting mripatmu

(49) salah s(aw)ijining sarana

(50) sakabèhing gegayuhanmu

(51) sajroning urip

(52) bebukaning serat punika

(53) lingganing tembung 'top of the mountain'

'ladle of the table'

'window of the bus'

'top hair of (an ear of) rice'

'shine of your eyes'

'any means' (literally, 'one seed of means')

'all your aspirations' (literally, the whole of ...')

'the whole life' (literally, 'the inner of life')

'salutation of that letter'

'root of a word'

Meronymic relations in Javanese also include comparatives, such as the relation between kalih 'two' and bagéan 'part' in sentence (54).

(54) Bagé-an-ipun priya tikel kalih-ing bagé-an-ipun wanita. share-NMLZ-GEN man more.than two-GEN share-NMLZ-GEN woman

'The proportion of men is more than twice (of) the proportion of women.' [KR]

\subsection{SUbJECT RELATION}

The genitive suffix -ing can relate the subject to its activity, state, or property. In Latin grammars, this is known as genitivus subiectivus. The formula in (55) explains this relation and it can be paraphrased as in (56).

(55) N1 is performed by N2 $\rightarrow$ N1-ing N2

(56) N1 dilakoni déning N2

Here, the first nominal which bears the suffix -ing represents the activity that is performed by the second nominal. The "activity" is normally not a verb, but either a nominalization like panjaluk 'request' (from the root jaluk 'ask for'), or a nominal root which describes an activity like jerit 'crying', or a state or property like regeng 'lively'. The examples in (57) to (62) illustrate this relation. In all cases, -ing can be replaced by -é/-ipun without a change in meaning. 
(57) jeriting bayi

(58) pangamuking angin

(59) panjaluking kanca

(60) ocèh(an)ing manuk

(61) kersaning sing gawé urip

(62) regenging swasana 'the crying of the baby'

'raging of the wind'

'request of a friend'

'twitter of a bird'

'will of the one who made life (= God)'

'liveliness of the atmosphere'

\subsection{OBJeCt RELATION}

The opposite of subject relation as described in Section 5.3 is an object relation between the two nominals which are connected by -ing. This relation is termed genitivus obiectivus in Latin grammars. The formula in (63) illustrates the object relation between the two nominals, which can be expressed as in (64).

(63) N2 is object of N1 $\rightarrow$ N1-ing N2

(64) N2 di-N1 déning uwong

This formula states that, when -ing attaches to the first nominal whose root is transitive and can therefore have a direct object, the second nominal denotes that object. The Javanese paraphrase uses a passive construction to convey the meaning of such object relations. Only a few examples of this type have been found and are listed in (65) to (69).

(65) kumpulaning tembung

(66) dhapukaning paribasan

(67) wedharaning tembung

(68) dhedhapukaning serat punika

(69) kateranganing tegesipun tembung 'collection of words'

'arrangement of proverbs'

'expression of words'

'arrangements of those letters'

'explanation of the meaning of the word'

There is one attested case of two nominals which are the object of the activity which carries the genitive suffix -ing, illustrated in (70). Here, the activity is the nominalized form of sambung 'associate, connect', and the objects are manungsa 'human being' and alam urip 'living nature'.
se-sambung-an-ing
manungsa lan alam
urip-é
NMLZ-Connect-NMLZ-GEN human and nature life-3sG.POSS
'the connection of man and his living nature' [NG]

\subsection{IMPOSSIBLE CONSTRUCTIONS}

In this section, I describe two instances in which the suffix -ing cannot be used, although both of them constitute a relation between two nominals. One includes possession or actions of real and living persons referred to by name. The other construction involves descriptive relations, in which the second nominal modifies the first. 


\subsubsection{Possession or actions of concrete and living people}

It has been observed by other researchers before (see Section 3 ) that -ing seems to be unfavoured or even ungrammatical in some constructions. The case in which this is most obvious is in possessive constructions with real (living) people who are referred to by name. There is no attested example of a genitive construction with -ing followed by the name of a living person. Compare the attested construction in (71) with the ungrammatical NP in (72).

(71) dalem-ing raka

house-GEN older.brother

'the house of the older brother' [KR]

(72) *dalem-ing Bu Hartati

house-GEN Mrs PN.F

(intended: 'the house of Mrs Hartati' [KR])

Although in both cases the possessor refers to a real person, as attested in my corpus, (72) is considered ungrammatical by my consultants. The reason (71) is permitted is that it is taken from a story from the past in which raka 'older brother' refers to the brother of the former Prince of Blitar who lived in the eighteenth century. ${ }^{11}$ In contrast, (72) is not possible because the possessor is a proper name.

The construction in (73) is from a poem, in which the person is described as a friend of the moon. This is permitted by Javanese syntax because the moon does not refer to a real person with a name. In contrast, the genitive construction in (74) is not permitted because it is about a friend of a person with a proper name.

(73) Tinansah dadi kanca-ning rembulan. always become friend-GEN moon '[You] will always be a friend of the moon.' [NG]
*Aku kanca-ning Mas
Andit.
1sG friend-GEN older.brother PN.M
(intended: 'I'm a friend of Andit.' [NG])

Now compare the attested constructions with anak 'offspring' in (75) to (83), with the ungrammatical constructions in (84) to (88). It seems that -ing is only permitted in NPs with people where one of the following two conditions are met: either the person is unspecific, as in (75) to (81), or the nominal refers to

${ }_{11}$ The sentence is taken from the Babad Kartasura II, the Chronicles of Kartasura Vol. II: Saha bala sigra prapta lampahira Kapurubayan nuli Pangeran Balitar manjing daleming raka kang wadya penuh ing jawi wong Kapurbayan samya Kapurbayan samya kagyat ningali 'And then the troops hastily made their way to Kapurbayan, then the Prince of Blitar entered the house of his elder brother, while the troops were waiting in droves outside, and the people from Kapurbayan were aghast to see them all'. 
a specific but well-known deceased person or supernatural being, as in (82) and $(83) \cdot{ }^{12}$

(75) anaking priyayi

(76) anaking wong liya

(77) anaking anak

(78) anaking sedulur

(79) anaking putu

(80) anaking buyut

(81) anaking canggah

(82) anaking Dipati Suradimenggala

(83) anaking Gusti Allah

(84) *anaking Bu Nanik

(85) *anaking Pak Bud

(86) *anaking Mas Hendra

(87) *anaking Mbak Déwi

(88) *anaking Mbah Nun 'the child of the official'

'the child of someone else'

'the child of the child

'the child of one's relative'

'the child of one's grandchild'

'the child of one's great-grandchild'

'the child of one's great-great-grandchild'

'the child of Regent Suradimenggala'

'child of God'

(intended: 'the child of Mrs Nanik')

(intended: 'the child of Mrs Budi')

(intended: 'the child of Hendra')

(intended: 'the child of Ms Dewi')

(intended: 'the child of Granny Nun')

Further ungrammatical constructions are listed in Gina et al. (1987: 113), repeated here in (89) to (91). My consultants also confirm that these examples cannot take -ing, and that the suffix -é/-ipun is required instead.

inisiatip-é / *inisiatip-ing Ki Hajar Dewantara
initiative-GEN / initiative-GEN Mr PN.M PN.M
the initiative of Mr Hajar Dewantara' [NG]

(90) bayar-é / *bayar-ing Présidhén payment-GEN / payment-GEN president 'the salary of the President' [NG]

$$
\begin{aligned}
& \text { pidhaton-é / *pidhaton-ing Perdana Menteri } \\
& \text { speech-GEN / speech-GEN prime minister } \\
& \text { 'the speech of the Prime Minister' [NG] }
\end{aligned}
$$

\subsubsection{Nominal compounds}

Javanese makes a syntactic distinction between two types of NPs, one involves a genitive construction that requires a genitive suffix (see Section 2) and the other is nominal compounding, in which the second nominal functions as a specifier of

${ }^{12}$ I thank the anonymous reviewer who suggested that the reason the constructions in (75) to (83) are permitted whereas (84) to (88) are not might have to do with the specificity of the person. However, the specificity criterion would not permit the examples (82) and (83), therefore I have added the criterion that the person must be deceased (and probably well-known) or a supernatural being. A more fine-honed answer to this question certainly requires further investigation. 
the first. Cross-linguistically, it has been observed that nominal compounds can be expressed by a genitive construction (S. Pepper 2020: 155-156), for example, in Latin by a genitivus explicatious. However, nominal compounds in Javanese are never express by a genitive construction but by simple juxtaposition of the nominals instead (see Pepper 2020: 145-146 for a typological overview of this type of compounding).

Compare example (92) with (93) below. In (92), the second nominal dhokter 'doctor' specifies the first nominal klambi 'clothes', and the NP klambi dhokter means 'a doctor's coat, a white coat', not 'the coat of a (specific) doctor'. Example (93) is an infelicitous sentence (marked by the hash sign), because Ali cannot normally buy a coat which belongs to a specific doctor. The sentence becomes acceptable when a relative clause which specifies the coat is added, as in (94).

(92) Ali tuku klambi dhokter. PN.M buy clothes doctor

'Ali bought a doctor's coat.' [NG] (Gina et al. 1987: 37)

(93) \#Ali tuku klambi-né dhokter.

PN.M buy clothes-GEN doctor

'Ali bought the clothes of the doctor.' [NG] (Gina et al. 1987: 37)

(94) Ali tuku klambi-né dhokter sing wis ora di-enggo manèh. PN.M buy clothes-GEN doctor REL already NEG pass-wear again 'Ali bought the clothes of the doctor that weren't worn anymore.' [NG] (Gina et al. 1987: 37)

From what I have described in Section 5.1, one would expect that the suffix -é in (94) could be replaced by -ing, because of a possessive relationship existing between the doctor and the clothes. However, because the doctor is a real person, the use of -ing is blocked (see Section 5.5.1). The important point for this section is that NPs as in (92) can never take the genitive suffix -ing. The structure for descriptive relations is set out in (95) and paraphrased in Javanese in (96).

(95) N2 is a kind of N1

(96) N2 ya iku jinis N1

Some examples in which the suffix -ing (and also -é/-ipun) is ungrammatical are listed in (97) to (102).

(97) kembang ${ }^{*}$-ing) mlathi

(98) wit(*-ing) munggur

(99) woh ${ }^{*}$-ing) mojo

(100) kompleks( ${ }^{*}$-ing) pondok pesantren

(101) guru(*-ning) basa

(102) sepédhah ${ }^{*}$-ing) onthèl 'jasmine flower'

'Samanea saman tree'

'bael fruit'

'Islamic boarding house complex'

'language teacher'

'bicycle' 


\subsection{IN FIXED EXPRESSIONS}

While the suffix -ing is largely absent from the spoken language and nearly unheard of in the varieties farther away from Central Java, it still occurs in a variety of fixed expressions, proverbs, collocations, and advices for daily living. Table 1 contains a collection of the most common phrases along with their literal and free translations, all of which were familiar to my consultants from Yogyakarta, whereas my consultant from Surabaya did not recognize any except for sawijining dina 'one day'.

\begin{tabular}{|c|c|c|}
\hline Javanese & Literal translation & Free translation \\
\hline agama ageming aji & 'religion used by the king' & 'tradition adhered to by kings' \\
\hline $\begin{array}{l}\text { aja lali marang sapadha-padhaning } \\
\text { tumitah }\end{array}$ & $\begin{array}{l}\text { 'don't forget about the same ones } \\
\text { of your shape' }\end{array}$ & $\begin{array}{l}\text { 'don't forget about your fellow } \\
\text { men' }\end{array}$ \\
\hline $\begin{array}{l}\text { ajining dhiri dumunung ana ing } \\
\text { lathi, ajining raga ana ing busana }\end{array}$ & $\begin{array}{l}\text { 'the value of one's self is at the } \\
\text { lips, the value of one's body is } \\
\text { in the garment' }\end{array}$ & $\begin{array}{l}\text { 'your real value is judged by } \\
\text { what you say, your appearance } \\
\text { is measured by what you wear' }\end{array}$ \\
\hline ancik-ancik pucuking eri & 'reach the tip of the thorn' & 'in a precarious position' \\
\hline antebing tékad & 'firmness of determination' & 'firm will, resolution' \\
\hline babaring lelakon & 'proliferation of the biography' & 'unfolding of a life-story' \\
\hline beda-beda pandumaning dumadi & $\begin{array}{l}\text { 'everyone's share of genesis is } \\
\text { different' }\end{array}$ & $\begin{array}{l}\text { 'God distributes his grace } \\
\text { differently' }\end{array}$ \\
\hline cekaking rembug & 'brevity of the topic' & 'to make a long story short' \\
\hline dadi panjanging kidung & 'become the length of a poem' & 'famous, renowned' \\
\hline $\begin{array}{l}\text { dumadining sira iku lantaran anane } \\
\text { bapa biyung ira }\end{array}$ & $\begin{array}{l}\text { 'the genesis of you is because of } \\
\text { the existence of your parents' }\end{array}$ & 'circle of life' \\
\hline gelah-gelahing jagad & 'the dregs of the world' & 'the dregs of society' \\
\hline kodhok sajroning bathok & 'frog in a coconut shell' & 'narrow-minded' \\
\hline lebak ilining banyu & 'the valley is the flow of water' & 'subordinates are always blamed' \\
\hline lelananging jagad & 'the one man of the world' & 'the bravest man in the world' \\
\hline lenging cipta & 'focal point of thoughts' & 'the centre of one's thoughts' \\
\hline manunggaling kawula gusti & 'unity of servant and God' & $\begin{array}{l}\text { 'unity between the ordinary } \\
\text { people and higher authorities' }\end{array}$ \\
\hline marak ing pangayunaning Pangéran & 'sit humbly in front of the Lord' & 'pass away' \\
\hline ngundhuh wohing pakerti & 'pick the fruit of character' & ‘you reap what you sow’ \\
\hline $\begin{array}{l}\text { ora tedhas tapak paluning pandhé } \\
\text { sisaning gurénda }\end{array}$ & $\begin{array}{l}\text { 'cannot be cut by a blacksmith's } \\
\text { mallet, residue of the grinder' }\end{array}$ & 'magically invulnerable' \\
\hline pusering tanah Jawa & 'centre of the Javanese land' & 'area of the Sultanate of Mataram' \\
\hline salumahing bumi, sakurebing langit & $\begin{array}{l}\text { 'the upper side of Earth, the } \\
\text { underside of the sky' }\end{array}$ & 'everywhere under the sun' \\
\hline saumuring jagung & 'the life of corn' & $\begin{array}{l}\text { 'very short time, just three } \\
\text { months' }\end{array}$ \\
\hline $\begin{array}{l}\text { sawijining dina }(\mathrm{NG}) / \text { satunggaling } \\
\text { dinten }(\mathrm{KR})\end{array}$ & 'a seed of the day' & $\begin{array}{l}\text { 'one day, some day, once upon } \\
\text { a time' }\end{array}$ \\
\hline witing tresna jalaran saka kulina & 'origin of love due to habit' & $\begin{array}{l}\text { 'fall in love with someone because } \\
\text { you know him/her well' }\end{array}$ \\
\hline wolak-waliking jaman & 'opposite side of the era' & 'times have changed' \\
\hline wrangkaning ratu & 'sheath of the monarch' & 'Prime Minister, Governor' \\
\hline
\end{tabular}

Table 1. Common expressions with -ing. 
I have chosen babaring lelakon as the title of this article. The literal meaning of this expression is 'proliferation of someone's biography', which in our case refers to the historical development of the suffix -ing. This expression contains the root babar, which is the Krama equivalent to lair 'birth'. It can also be used as verb mbabar ' give birth'. However, the original meaning of babar is 'unfold, open', attested in Old Javanese as ambabar 'disperse, unfold' (Zoetmulder and Robson 1982: 183). The form lelakon 'biography, destiny' is derived from le-laku-an, from the root laku 'walk, progress', also attested in Old Javanese with the same meaning (Zoetmulder and Robson 1982: 960).

There are many more fixed expressions which contain the genitive suffix -ing. Table 2 is a list of those phrases which were only recognized by one of my consultants but not by both.

\begin{tabular}{|c|c|c|}
\hline Javanese & Literal translation & Free translation \\
\hline ancasing sedya & 'goal of the plan' & 'definite intention' \\
\hline $\begin{array}{l}\text { celak coloking Hyang Widi, momor } \\
\text { pamoring sawujud }\end{array}$ & $\begin{array}{l}\text { 'close to the torch of Lord } \\
\text { Destiny (God), and blend in } \\
\text { with the crowd of one's shape' }\end{array}$ & $\begin{array}{l}\text { 'strengthen your relationship } \\
\text { with God and with other people' }\end{array}$ \\
\hline cempéning Allah (KR) & 'lamb of God' & 'Lamb of God' \\
\hline gancanging carita & 'celerity/haste of the narration' & 'to make a long story short' \\
\hline krejeting ati & 'twitch of the heart' & 'feeling which arises in the heart' \\
\hline kridha lumahing asta & 'pleasure is the surface of hand' & 'begging, rather take than give' \\
\hline $\begin{array}{l}\text { manungsa iku saka dating } \\
\text { Pangéran mula uga darbé sipating } \\
\text { Pangéran }\end{array}$ & $\begin{array}{l}\text { 'man is from the essence of the } \\
\text { Lord, hence he also possesses the } \\
\text { nature of the Lord' }\end{array}$ & religious saying \\
\hline nambut silaning akrama & 'receive the act of marriage' & 'enter into matrimony' \\
\hline nggolèki tapaking kontul nglayang & $\begin{array}{l}\text { 'search the traces of a flying } \\
\text { heron' }\end{array}$ & 'attempt the impossible' \\
\hline $\begin{array}{l}\text { owah gingsiring kaanan iku } \\
\text { saka karsaning Pangéran Kang } \\
\text { Murbèng Jagad }\end{array}$ & $\begin{array}{l}\text { 'constant change in the situation } \\
\text { is the will of the Lord who is the } \\
\text { ruler of the world' }\end{array}$ & $\begin{array}{l}\text { 'all changes in our lives are God's } \\
\text { will' }\end{array}$ \\
\hline sangkan-paraning dumadi & 'start and course of creation' & 'origin and purpose of creation' \\
\hline suwé mijet wohing ranti & $\begin{array}{l}\text { 'knead the small fruits of a tree } \\
\text { for a long time' }\end{array}$ & 'very easy, a piece of cake' \\
\hline tancebing langit & 'tip of the sky' & 'horizon' \\
\hline telenging ati & 'innermost of the heart' & 'most beloved person/thing' \\
\hline tempuking nétra & 'merger of the eyes' & 'a meeting of the eyes' \\
\hline trahing kusuma rembesing madu & 'lineage of nobility, flow of honey' & 'of noble descent' \\
\hline wimbaning lèk & 'emergence of the visible moon' & 'the time of the new moon' \\
\hline & 'root of the heart' & 'beloved one' \\
\hline
\end{tabular}

Table 2. Further expressions with -ing.

There is at least one example of -ing being used where it should not, because it does not function as a linker between two nominals. This is the case of sarèhning, which is a literary substitute for sarèhné or sarèhnipun 'since, in view of the fact that', exemplified in (103). 
(103) Sarèhning wis subuh, aku arep semèdi.

since already dawn 1sG will meditate

'Since it's already dawn, I want to meditate now.' [NG]

\section{CONCLUSION}

In this article, I have attempted an analysis of the Javanese suffix -ing, which has so far received little attention in the literature. Although it has been observed before by some authors that there is a difference in usage between the common genitive suffix -é/-ipun and the more formal suffix -ing, the latter has often been neglected from grammatical descriptions of Javanese, perhaps because it is rarely used in the spoken language.

Two observations can be made with regard to the use of -ing: (1) It is a formal and literary suffix which can be replaced by -é/-ipun in all cases in the spoken language. It is commonly used in four different types of genitive constructions. (2) There are at least two genitive constructions, in which -ing cannot be replaced by -é/-ipun. The second point is perhaps the most interesting. When the possessor in a genitive construction is a proper name of a real and living person, or when the second nominal modifies the first, then -ing cannot be used. In the first case, -é/-ipun must be used, and in the second case, no suffix can be used.

However, more in-depth investigation is still needed to determine the exact constraints of -ing. This study along with Nardiati's (2016) investigation forms a good basis for further research into the patterns and functions of Javanese suffixation in genitive constructions.

$\begin{array}{ll}\text { ABBREVIATIONS } & \\ 1 & \text { first person } \\ 2 & \text { second person } \\ 3 & \text { third person } \\ - & \text { morpheme boundary } \\ \sim & \text { reduplication } \\ \text { app } & \text { applicative } \\ \text { ART } & \text { article } \\ \text { AV } & \text { agent voice } \\ \text { DEF } & \text { definite } \\ \text { DEM } & \text { demonstrative } \\ \text { DIST } & \text { distal } \\ \text { F } & \text { feminine } \\ \text { GEN } & \text { genitive } \\ \text { GEO } & \text { geographical } \\ \text { HON } & \text { honorific } \\ \text { HUM } & \text { human } \\ \text { IMP } & \text { imperative } \\ \text { ING } & \text { suffix -ing } \\ \text { KR } & \text { Krama speech level } \\ \text { M } & \text { masculine }\end{array}$




$\begin{array}{ll}\text { N } & \text { noun } \\ \text { NEG } & \text { negation } \\ \text { NG } & \text { Ngoko speech level } \\ \text { NMLZ } & \text { nominalizer } \\ \text { NP } & \text { nominal phrase } \\ \text { PASS } & \text { passive } \\ \text { PN } & \text { proper name } \\ \text { POSS } & \text { possessive } \\ \text { PROG } & \text { progressive } \\ \text { RED } & \text { reduplicant } \\ \text { REL } & \text { relative pronoun } \\ \text { SG } & \text { singular }\end{array}$

\section{REFERENCES}

Adelaar, A. 2011. "Javanese-aké and -akan; A short history", Oceanic Linguistics 50(2): 338-349.

Alkitab Mobile. 2006. Alkitab Mobile. [Https://alkitab.mobi/jawa2006/ Mat/10/.]

Arps, B., E. Bogaerts, and W. van der Molen. 2000. Hedendaags Javaans; Een leerboek. Leiden: Universiteit Leiden.

Babad Tanah Jawi. 1939-1941. Babad Tanah Jawi; Nyariyosakĕn sajarah wiwit saking nabi Adam dumugi para dewa, lajĕng para ratu ing tanah Jawi wiwit saking Bathara Brama sarta Bathara Wisnu dumugi nagari Pajajaran, tuwin madĕgipun nagari Majapahit. 31 vols. Batavia: Balé Pustaka.

Baroroh, K. and Mulyadi. 2020. "Possessive expressions in Javanese", International Journal of Cultural and Art Studies 4(1): 42-53.

Darusuprapta. 2002. Pedoman penulisan aksara Jawa. Yogyakarta: Yayasan Pustaka Nusantara.

Dwi Puspitorini. 2015. Afiks verbal bahasa Jawa Kuno. PhD thesis, Universitas Indonesia.

Ewing, M.C. 2010. "Reference and recovery in Cirebon Javanese", Australian Journal of Linguistics 21(1): 25-47.

Favre, L.P. 1866. Grammaire javanais. Paris: L'imprimerie Impériale.

Geertz, C. 1977. "Linguistic etiquette”, in: Joshua A. Fishman and Thomas A. Sebeok (eds), Readings in the sociology of language, pp. 282-295. The Hague: Mouton.

Gina et al. 1987. Frase nomina dalam bahasa Jawa. Jakarta: Pusat Pembinaan dan Pengembangan Bahasa, Departemen Pendidikan dan Kebudayaan.

Grangé, P. 2015. "The Indonesian verbal suffix -nya; Nominalization or subordination?", Wacana, Journal of the Humanities of Indonesia Vol. 16 No. 1: 133-166.

Hayward, K. 1995. "Some notes on the noun phrase in Javanese", Indonesia Circle 65: 42-56.

Kern, H. 1871. Kawi-studiën; Arjuna-Wiwâha, zang I en II. In tekst en vertaling met aanteekeningen en inleiding. The Hague: Martinus Nijhoff.

Kiliaan, H.N. 1919. Javaansche spraakkunst. The Hague: Martinus Nijhoff. 
Kisyani-Laksono. 2004. “Identifikasi kosakata krama dalam bahasa Jawa dialek Jawa Timur dan dialek Osing", Linguistik Indonesia 22: 37-64.

Kitab Suci Jawa. 1962. Kitab Suci Jawa. [Https:/ / www.sastra.org/agama-dankepercayaan/kitab-suci/1546-kitab-suci-anonim-1962-bagian-3.]

Krauße, D. 2017. “A description of Surabayan Javanese with special reference to its linguistic etiquette". MA thesis, Goethe University of Frankfurt.

Krauße, D. 2018. "Polite vocabulary in the Javanese language of Surabaya", Wacana, Journal of the Humanities of Indonesia Vol. 19 No. 1: 58-99.

Lyons, C. 1999. Definiteness. Cambridge: Cambridge University Press.

Meij, D. van der. 2010. "Cross- and trans-language morphology; The lexicography of Indonesian names", Wacana, Journal of the Humanities of Indonesia Vol. 12 No. 2: 345-368.

Molen, W. van der. 2015. “An introduction to Old Javanese”. [Paper, ILCAA Intensive Language Course, Tokyo, 17 August - 4 September.]

Nardiati, S. 2007. Struktur frasa nominal pada wicara pernikahan Jawa. Yogyakarta: Balai Bahasa.

Nardiati, S. 2016. "Perilaku satuan lingual -(n)ing dalam bahasa Jawa", Widyaparwa 44(2): 85-96.

Nardiati, S., S. Sudira, Widada, and Sudaryanto. 1995. Sistem morfemis nomina bahasa Jawa-Indonesia; Suatu studi kontrastif. Jakarta: Pusat Pembinaan dan Pengembangan Bahasa, Departemen Pendidikan dan Kebudayaan.

Pawarta Bahasa Jawa. 2020. Pawarta Bahasa Jawa. [Retrieved from: https:/ / pawartabahasajawa.blogspot.com/.]

Pepper, S. 2020. The typology and semantics of binominal lexemes; Noun-noun compounds and their functional equivalents. PhD thesis, University of Oslo.

Poedjosoedarmo, S. 1968. "Javanese speech levels", Indonesia 6: 54-81.

Poedjosoedarmo, S. 1969. "Wordlist of non-Ngoko vocabularies", Indonesia 7: 165-190.

Poensen, C. 1897. Grammatica der Javaansche taal. Leiden: E.J. Brill.

Poerwadarminta, W.J.S. 1939. Baoesastra Djawa. Groningen: Wolters.

Pusaka Jawi. 1935. Pusaka Jawi. Yogyakarta: Java Instituut.

Ras, J.J. 1985. Inleiding tot het modern Javaans. Dordrecht: Foris.

Reksa Pustaka. 1962. “Kitab Suci”. [Retrieved from: https:/ / www.sastra.org/ katalog/ judul?ti_id=1962.]

Robson, S. 1992. Javanese grammar for students. Clayton: Monash University.

Robson, S. and S. Wibisono. 2002. Javanese English dictionary. Hong Kong: Periplus.

Roorda, T. 1855. Javaansche grammatica; Benevens een leesboek tot oefening in de Javaansche taal. Eerste deel; Grammatica. Amsterdam: Johannes Müller.

Roorda, T. 1874. Beknopte Javaansche grammatica, benevens een leesboek tot oefening in de Javaansche taal. Amsterdam: Johannes Müller.

Sêrat Jăngka Jayabaya. 1938. Sêrat Jăngka Jayabaya. Surakarta: Sadoe Boedi.

Shiohara, A. and K. Artawa. 2015. "The definite marker in Balinese", in: Proceedings of the Second International Workshop on "Information structure of Austronesian languages", pp. 141-159. Tokyo: Tokyo University of Foreign Studies [Linguistic Dynamics Science Project 2 (LingDy2).] 
Sneddon, J.N. 2010. Indonesian reference grammar. Second edition. Crows Nest NSW: Allen \& Unwin.

Sukarno. 2008. The study of interpersonal meanings in Javanese wedding pranatacara genre. PhD thesis, State University of Semarang.

Teselkin, A.S. 1972. Old Javanese (Kawi). Translated and edited by John M. Echols. Ithaca, NY: Cornell University.

Uhlenbeck, E.M. 1960. De systematiek der Javaanse pronomina. The Hague: Martinus Nijhoff.

Uhlenbeck, E.M. 1968. "Personal pronouns and pronominal suffixes in Old Javanese", Lingua 21: 466-482.

Villerius, S. 2018. Development of Surinamese Javanese; Language contact and change in a multilingual context. PhD thesis, Universiteit Utrecht. [LOT.]

Wedhawati, W.E.S. Nurlina, and E. Setiyanto (eds). 2001. Tata bahasa Jawa mutakhir. Jakarta: Pusat Bahasa.

Wessing, R. 2015. "The Javanese suffix $-(n) e^{\prime \prime}$, Indonesia and the Malay World 43(127): 431-440.

Zoetmulder, P.J. and S.O. Robson. 1982. Old Javanese-English dictionary. The Hague: Martinus Nijhoff.

Zurbuchen, M.S. 1976. Introduction to Old Javanese language and literature; A Kawi prose anthology. Ann Arbor, MI: The University of Michigan. 